РОЗЕНБЕРГ Валерия Ивановна - аспирант кафедры российской политики факультета политологии Московского государственного университета им. М.В. Ломоносова (119991, Россия, г. Москва, Ломоносовский пр-кт, корп. 4 «Шуваловский»; liorkvalery@gmail.com)

\title{
ОСОБЕННОСТИ ИСПОЛЬЗОВАНИЯ ПЕРЕГОВОРНЫХ ТЕХНОЛОГИЙ ПРИ УРЕГУЛИРОВАНИИ ВОЕННО- ПОЛИТИЧЕСКОГО КОНФЛИКТА В СИРИИ
}

\begin{abstract}
Аннотация. Статья посвящена особенностям использования переговорных технологий при урегулировании военно-политического конфликта в Сирии. В статье обосновывается вывод, что конфликт в Сирии является одним из самых трудноразрешимых в современном мире. Международное вмешательство и серия многосторонних переговорных процессов не смогли разрешить конфликт и обозначили несовершенство классических дипломатических методов. Таким образом, сирийский конфликт позволяет выявить основные проблемы мирного урегулирования и пути комплексного воздействия на противоборствующие стороны.
\end{abstract}

Ключевые слова: международные переговоры, военно-политические конфликты, конфликтология, конфликты, переговорные технологии, разрешение конфликтов, дипломатия, Сирия

$\mathrm{B}_{\mathrm{r}}$ мире национальных интересов главными методами управления международными конфликтами долгое время являлись традиционные дипломатические средства воздействия. Переговоры в мире национальных интересов означают уравновешивание или обмен интересами конкурирующих государств друг с другом или поиск общих интересов, которые могут стать основой для достижения соглашения даже перед лицом других конфликтующих интересов. Поэтому переговоры традиционно относят к старейшим методам урегулирования конфликтов, и, безусловно, отказаться от них невозможно. Конечно, в современном мире международная переговорная практика значительно усложнилась, приобрела разнообразные формы, расширила проблематику и т.П., но тем не менее переговоры продолжают оставаться своеобразным мостом между двумя видами политической деятельности - борьбой и сотрудничеством [Василенко И., Василенко Е. 2017]. Поэтому не удивительно, что переговорные процессы стали одной из первых попыток мирового сообщества урегулировать сирийский конфликт.

Но почему мирное урегулирование не всегда работает? Потому что некоторые конфликты обладают чертами, которые делают их сложно поддающимися урегулированию.

Конфликты, сложно поддающиеся урегулированию, как правило, связаны с длительной напряженностью, использованием деструктивных средств, подозрительностью и недоверием, подстрекательской риторикой и поляризованными целями, которые обычно преподносятся как ультиматумы [Vuković, Bernabei 2019: 410]. Сохраняющееся сопротивление решению, достигнутому путем переговоров, было определено в качестве важнейшего индикатора неразрешимости конфликта в Сирии. Во время попыток его урегулирования наблюдалось резкое сопротивление миротворчеству: ни Женевский процесс, возглавляемый ООН, ни последующий Астанинский процесс, организованный Россией и Турцией, не смогли привести стороны к соглашению. Вместо этого участвовавшие в переговорных процессах делегации использовали любую воз- 
можность, чтобы выразить взаимное пренебрежение и решительно отвергнуть предложенные решения.

Подобные длительные конфликты приводят сразу к нескольким последствиям: они увеличивают невозвратные издержки сторон и служат источником формирования привычки. Конфликт становится «неотвратимым», а целью становится «полная победа» одной из сторон. После этого любой вид компромисса уже расценивается как предательство или поражение.

Следуюшим признаком трудноразрешимого конфликта являются противоположные цели сторон, абсолютно несовместимые друг с другом. Стороны просто не могут достигнуть договоренностей без серьезных уступок в списке своих требований, и чем активнее конфликт развивается, тем менее вероятны успешные переговоры.

И еще одна черта - «нормализация враждебности и насилия». Она способствует процессу развития у новых поколений фатализма, который считает военные действия неотвратимыми и, соответственно, готовит каждого для жизни в условиях войны.

Конфликты становятся трудноразрешимыми по мере того, как стороны прибегают к эскалационным мерам, разрабатывают конфронтационные и пагубные стратегии и формулируют свои цели как набор, казалось бы, непримиримых проблем.

С начала гражданской войны у Сирии было 4 посредника для мирного урегулирования конфликта - Лига арабских государств, Организация Объединенных Наций, Россия и Международная группа поддержки Сирии. Эти посредники провели 9 мирных процессов, результатом которых стали десятки конференций, бесчисленные переговоры и нулевые ощутимые результаты.

В конце 2012 г. на переговорах в Женеве впервые удалось объединить в одном зале представителей власти и оппозиции Сирии, но кроме этого почти не был достигнут никакой прогресс в урегулировании конфликта.

Параметры и сфера охвата соглашений, обсуждавшихся на различных этапах переговорных процессов, постепенно менялись с течением времени, но на первом этапе - включая первоначальные усилия Лиги арабских государств, план Аннана из 6 пунктов и Женевские переговорные процессы - все участники оставались приверженными своей первоначальной позиции, решительно поддерживая Асада или выступая за его исключение из органов власти.

В феврале 2012 го. Кофи Аннан разработал проект своего 6-пунктного плана, в котором намеренно исключалось какое-либо явное упоминание роли президента Сирии в будущем правительстве. План был сосредоточен на неполитических вопросах и был вскоре отвергнут постоянными членами СБ ООН.

Женевское коммюнике, подписанное в июне 2012 г., на первый взгляд казалось первым шагом на пути к компромиссу. В нем содержался призыв к передаче власти переходному органу управления, обладающему всей полнотой исполнительной власти, состоящему, в формулировке самого Коммюнике, из «членов правительства и оппозиции и других групп», который должен быть «сформирован на основе взаимного согласия» 1 . Однако двусмысленность этой формулировки дала каждой из сторон право вето на принятие коммюнике, что вновь привело к предсказуемому тупику.

Вторая Женевская конференция стала заключительным этапом в мирном процессе под руководством ООН. Это был последний раз, когда на переговорах серьезно обсуждалось место Асада в переходном правительстве. Некоторые

1 Заключительное коммюнике Группы действий по Сирии. Женева, 30 июня 2012 г. Доступ: https://gigabaza.ru/doc/49200-p3.html (проверено 12.07.2020). 
считают, что «Женева II» добилась небольших успехов: на переговорах впервые с начала войны режим и оппозиция сели за один стол, и режим был вынужден разрешить эвакуацию женщин и детей из города Хомс [Zartman, Hinnebusch 2016: 16]. Однако раунды переговоров, организованные по поводу переходного правительства, закончились через 30 минут, т.к. представители власти Сирии настаивали на создании центра по борьбе с террористическими группировками, определение которых они расширили, включив в него большинство оппозиционных групп.

Начало военной операции России в Сирии в 2015 г. стало поворотным моментом в развитии сирийского конфликта. Вмешательство России развернуло ситуацию в пользу Башара Асада, недостаточную для объявления окончательной военной победы, но, безусловно, укрепившую переговорные позиции Дамаска [Ходынская-Голенищева 2019: 686].

После этого Женевский процесс под руководством ООН сместил акцент с политической цели создания переходного правительства на гуманитарные соглашения, ориентированные на помощь, прекращение огня и создание безопасных зон.

Запущенный 14 ноября 2015 г. Венский процесс стал совместным мероприятием Соединенных Штатов и России, направленным на возрождение затормозившегося Женевского процесса под руководством ООН. В конце концов, эти переговоры уступили место изменившему форму Женевскому процессу, который, в конечном счете, никогда больше не затрагивал тему нового правительства без Асада.

В связи с прекращением огня в декабре 2015 г. при посредничестве Турции Россия выступила в поддержку нового мирного процесса в Астане. Переговоры были основаны на политических целях. В первом раунде собрались лидеры 30 дружественных Анкаре оппозиционных групп. В мае 2015 г. была принята Астанинская декларация о политическом решении в Сирии, которая индоктринировала более широкий Астанинский процесс как процесс, который будет сфокусирован на формировании безопасных зон и рассмотрит ключевые политические вопросы.

Сирийский центр по наблюдению за соблюдением прав человека заявил, что прекращение огня привело к самому мирному периоду в 6-летней войне, причем месяц спустя после переговоров был отмечен наименьшим числом жертв среди гражданского населения с ноября 2011 г. [Phillips 2016: 229]. Однако в феврале 2020 г. на территории Сирии в Идлибе произошли ожесточенные вооруженные столкновения между сирийской армией и оппозицией при поддержке последней турецкими вооруженными силами. В данном столкновении понесла потери турецкая сторона, что стало поводом для нового витка конфликта. Турция объявила Сирию враждебной стороной и начала ответную военную операцию. 5 марта была предпринята попытка урегулирования конфликта на двустороннем переговорном процессе между лидерами России и Турции, после его завершения был подписан дополнительный протокол к меморандуму 2018 г. В документе было заверено соглашение о прекращении огня в Идлибской зоне и начале совместного российско-турецкого патрулирования ${ }^{1}$. Позднее в Центре примирения враждующих сторон в Сирии заявили о снижении числа обстрелов в сирийском Идлибе после договоренностей между Россией и Турцией.

1 Дополнительный протокол к Меморандуму о стабилизации обстановки в зоне деэскалации Идлиб от 17 сентября 2018 г. Доступ: https://www.mid.ru/foreign_policy/ international_safety/conflicts/-/asset_publisher/xIEMTQ3OvzcA/content/id/4072593 (проверено 11.03.2020). 
Таким образом, переговоры вновь позволили приостановить военные действия, но до полного разрешения конфликта еще далеко.

В заключение можно сказать, что современные длительные военные конфликты с течением времени приобретают все больше признаков трудноразрешимых, для которых полное мирное урегулирование становится уже практически невозможным. Чем больше сторона конфликта оказывается вовлеченной в процесс противостояния, тем менее вероятно, что она изменит свою позицию на переговорах. При этом конфликт в Сирии является одним из примеров, демонстрирующих, как комбинирование силовых и несиловых методов может стать причиной постепенной деэскалации конфликта. Поэтому, чтобы избежать неразрешимости конфликта, недостаточно искать решение только на основе мирных методов, напротив, необходимо найти такие комбинированные решения, которые снижают динамику конфликта и убирают факторы, оправдывающие прежде всего чрезмерные инвестиции в конфликт каждой из сторон.

\title{
Список литературы
}

Василенко И. А., Василенко Е.В. 2017. Эффективный переговорщик: личностный стиль, стратегии, технологии. М.: Международные отношения. 288 с.

Ходынская-Голенищева М.С. 2019. Сирия: трудный путь от войны к миру. Многосторонняя дипломатия сирийского урегулирования М.: Абрис. 720 с.

Phillips C. 2016. The Battle for Syria. International Rivalry in the New Middle East. Yale University Press. $330 \mathrm{p}$.

Vuković S., Bernabei B. 2019. Refining Intractability: A Case Study of Entrapment in the Syrian Civil War. - International Negotiation. Vol. 24 P. 407-436.

Zartman W.I., Hinnebusch R. 2016. UN Mediation in the Syrian Crisis: From Kofi Annan to Lakhdar Brahimi. N.Y.: International Peace Institute Publications. 28 p. Доступ: https://www.ipinst.org/wp-content/uploads/2016/03/IPI-Rpt-SyrianCrisis2.pdf (accessed 12.07.2020).

\section{PECULIARITIES OF THE USE OF NEGOTIATION TECHNOLOGIES IN THE SETTLEMENT OF THE MILITARY AND POLITICAL CONFLICT IN SYRIA}

\begin{abstract}
The article is devoted to the peculiarities of using negotiation technologies in settling the military and political conflict in Syria. The article substantiates the conclusion that the conflict in Syria is one of the most difficult to solve in the modern world. International intervention and a series of multilateral negotiation processes failed to resolve the conflict and pointed to the imperfection of classical diplomatic methods. Thus, the Syrian conflict makes it possible to identify the main problems of peaceful settlement and ways of complex influence on the opposing sides.
\end{abstract}

Keywords: international negotiations, military-political conflicts, conflictology, conflicts, negotiation technologies, conflict resolution, diplomacy, Syria 